This item was submitted to Loughborough's Research Repository by the author.

Items in Figshare are protected by copyright, with all rights reserved, unless otherwise indicated.

\title{
Personal crime against women: evidence from the 1982 British Crime Survey
}

PLEASE CITE THE PUBLISHED VERSION

PUBLISHER

(C) Blackwell

LICENCE

CC BY-NC-ND 4.0

\section{REPOSITORY RECORD}

Worrall, Anne, and Ken Pease. 2019. "Personal Crime Against Women: Evidence from the 1982 British Crime Survey”. figshare. https://hdl.handle.net/2134/1132. 


\title{
Personal Crime Against Women: Evidence from the 1982 British Crime Survey
}

\author{
ANNE WORRALI, and KEN PEASE \\ Anne Worrall is Lecturer in Social Work and Ken Pease is Senior \\ Lecturer in Social Administration, Universily of Manchester
}

Abstract: The concerns of feminist and radical writers for women as victims of crime are set out. Their criticisms of quantitative work in general and the British Crime Surpey in particular are mentioned. Data are presented from the survey showing that women victims of personal crime disproportionately suffer at the hands of people they know well, and of husbands esperially. Such crimes are reported to the police less than crimes against mates, and this is shown not to be ath artefact of the degree of injury caused. The paper's purpose is to show that survey dala, with all their imperfections, can be used to address the issues of concem.

The inadequacy of official responses to women victims of personal crime has been a major theme in radical and feminist research of recent years. It has been argued that there remains a legacy of thought in which a woman is an 'appropriate' victim unless she can 'demonstrate that she did not "descrve" to be attacked' (Dobash and Dobash 1980, p. 218). Police, magistrates and judges are frequently criticised in this literature for their reluctance to intervenc in 'matrimonial disputes'. Folk wisdom about women needing or enjoying punishment are perpetuated by, among others, the erstwhile campaigner Erin lizzey (Owens and Asheroft 1985, p. 27). Systematic research on the reasons why women return to violent partners (Binney $e$ al. 1981) yiclds more prosaic explanations: absence of aftcrnative accommodation, concern for children, and ill-founded optimism about a partners's capacity and/or motivation ta clange.

$R_{a p e}$ is a topic which gains particular attention in the literature being discussed. It is there argued that official responses reflect an underlying ambivalence. On the one hand, rape is viewed as a 'fate worse than death', the most calamitous event that can befall a (respectable) woman. On the other, 'it is a joke, a trivial or even a non-cxistent cvent that occurred only in the mind or imagination of the victim' (Wilson 1983, p. 61). Consequently, a woman is likely to be accused of cncouraging the crime and contributing to the event by her negligence or imprudence (Pattullo 1983, p. 22). It is therefore not surprising, so the argument runs, that much rape goes unrecorded because women feel too ashamed or frightened to report it, or because they anticipate a lack of sympathy or recognition of the event from the police. 
Sexual abuse within the family is perhaps the darkest secret to have been revealed in relation to women as crime victims (sec, for example, Nelson 1982). Once again, official responses have tended to minimise the seriousness of such abusc, preferring either to theorise it as normal (for certain 'types' of family) and consensual, or to attribute blame to the victim, who may be described as a provocative 'lolita'.

\section{The Reaction Against Conventional Research}

Women have responded to perceived official indifference to them as crime victims in two ways. First, they have organised in mutual support, particularly in terms of accommodation and counselling (for cxample, Women's Aid, Rape Crisis, Taboo - the Greater Manchester incest survivors group). Second, they have questioned those takcn-for-granted delinitions of the problem which are seen to cmanate from patriarchal institutions, such as the law, the judiciary and the police service - and conventional research. Although still cmbryonic, feminist theory in this area has begun to challenge the conventional (and by implication malcdesigned and male-dominated) research which appears to have cushioned and reassured those in authority about the extent and significance of violence against women. Elizabeth Wilson (1983) puts the position succinctly:

Rescarch can appear as a magical solution to unpleasant problems. A hight into research by Government bodies may be partly an attempt to shclve the problem (however expensive, rescarch costs a lot less than the provision of adequate sheler and income for all battered women and their children). Research conjures up a picture of white-coated experts who know more about the problem than the victims, in this case the women themselves. It is 'scientific', based on 'facts', free from the contamination of feelings and emotions that women bring to their testimony. (p. 89)

In the same vein, Hanmer and Saunders $(1984$, p. 11) feel forced to conclude that 'the interests of existing power-holders, largely men, are being served by knowing as little as possible about violence to women'. They argue that officially commissioned rescarch, such as the 1982 British Crime Survey, misrepresents the truc situation and 'will be used to undermine concern about violence to women' (p. 102). In order to counter this tendency, it is argued, women must undertake their own rescarch, which rejects the imposed language of a sexist society and 'starts from women's expericuce of wonicn's reality' (Stanley and Wisc 1983, p. 165).

In the light of these stringent charges, it becomes necessary to consider how justified these criticisms of the British Crime Survey may be. Such consideration is important in its own right, and even more so because local crime surveys, relying heavily on British Crime Survey questions and procedures, are increasingly being conducted as a means of identifying localised crime patterns. 'The faults and strengths of the British Grime Survey will thus be reflected in the local surveys.

'The British Crime Survey, the first national survey of crime victims in 
the United Kingdom, ccrtainly contains in its first report little about women as victims of crime. However, there are reasons of method which led to necessarily limited coverage in a number of arcas. The survey camot, for example, reveal victimless crimes, because it relies on victim report! Nor can it yicld information on most crimes by large organisations, since typically in such cases victims do not know of thcir own victimisation (sec, for example, Braithwaite 1984). As for women victims, it is hardly surprising that women victims were reluctant to talk about, for example, elomestic violence when 'their assailants may be in the same: room at the time of the interview' (Hough and Mayhew 1983, p. 34). It would indeed be dreadful if these categories of crime were to be taken to be unimportant on the basis of the survey. In that indirect sense there is criticism to be levelled. The authors of the survey must be cxoncrated from criticism. They revealed much of importance in the survey. Neither, though, should onc be content merely to assert that the British Crime Survey is, and by reason of methodology had to be, irrelevant to the special issue of crime against women.

The purpose of the present paper is to illustrate that, despite the problems of method described carlier, there are data in the British Crime Survey which suggest that the problem of personal crime against women is distinctive and important. The survey camot, and should not be taken to, demonstrate the full extent of the problem. That said, we feel that it can contribute to the arguments of those decply concerned with the issue, and that they should not eschew the results of quantitative research. To be brief and colloquial, we fecl that commentators like Hanmer and Saunders are in danger of throwing out the baby with the bathwater. More detailed analyses will become possible when data from the 1984 Survey are examined alongside the 1982 results. Analysis of the two samples together will allow a finer look at the problem (sec Hough and shechy 1986). For the moment, we are content to give some examples of how the issuc could be addressed.

\section{Personal Crime Against Women: What the Survey Suggests}

lior the purposes of this paper, personal crime was taken to comprise all crimes, including attempts, involving contact. Thus thefts from the person were included together with the more obvious contact crines like sexual offences and robbery. For the purposes of this study, the only relevant crimes were those where the victim saw the offender(s) and could classify them as known or unknown. One hundred and fifty-three such offences against women were captured by the survey, compared with 232 such offences where the victim was male (weighted data). The apparent rate of contact crime where the offender is secn is therefore higher for male than female victims. However, given the constraints on mentioning personal crimes to survey interviewers noted earlier, this difference should not be interpreted. Of more interest is the distribution of these offences according to the relationship between the victim and the offender. The suggestion from the Hanmer and Saunder's work, which is also implicit in the 
TABLE: 1

Viclim-Offender Relationships in Incidents of Personal Crime: British Crime Survey $1982(\mathrm{n}=$ weighted $\mathrm{n}$, total unweighted $\mathrm{n}=281$ )

\begin{tabular}{lllll} 
& $\begin{array}{l}\text { not } \\
\text { known }\end{array}$ & $\begin{array}{l}\text { known } \\
\text { casually }\end{array}$ & $\begin{array}{l}\text { known } \\
\text { well }\end{array}$ & Total \\
\hline $\begin{array}{l}\text { malc } \\
\text { victim }\end{array}$ & $129(56 \%)$ & $72(31 \%)$ & $31(13 \%)$ & $232(100 \%)$ \\
$\begin{array}{l}\text { femalc } \\
\text { victim }\end{array}$ & $74(49 \%)$ & $19(13 \%)$ & $59(39 \%)$ & $152(100 \%)$ \\
\hline Total & $203(53 \%)$ & $91(24 \%)$ & $90(23 \%)$ & $384(100 \%)$ \\
\hline
\end{tabular}

TABLE 2

Victim-Offender Relationships within 'known well' Calegory: Personal Crime Incidents in British Crime Survey $1982(\mathrm{n}=$ unweighted $\mathrm{n}$, total unwcighted $n=54)$

current or

former

neighbour, houschold

acquaintance, member or

other intimate spouse Total

\begin{tabular}{lcccc}
\hline $\begin{array}{l}\text { male } \\
\text { victim }\end{array}$ & $25(83 \%)$ & $5(17 \%)$ & $0(0 \%)$ & $30(100 \%)$ \\
$\begin{array}{l}\text { female } \\
\text { victim }\end{array}$ & $30(51 \%)$ & $8(14 \%)$ & $21(36 \%)$ & $59(100 \%)$ \\
\hline Total & $55(62 \%)$ & $13(15 \%)$ & $21(24 \%)$ & $89(100 \%)$ \\
\hline
\end{tabular}

remarks of Hough and Maybew cited above, would be that women underreport to interviewers violence against them committed by those they know well, in particular by their husbands. Given that wholly plausible suggestion Table $l$ is surprising. It shows that those whom women identify as having committed contact crime against them are disproportionately well-known to them. Men victims are more likely to recount offences by strangers or acquaintances $\left(\mathrm{X}^{2}=39.92,2 \mathrm{df}, \mathrm{p}<0.001\right)$. The obvious next question is - who are the offenders in cases where the offender is well known to the victim? Table 2 shows that offenders are indecd different according to victim gender $\left(\mathrm{X}^{2}=12.21,2 \mathrm{df}, \mathrm{p}<0.005\right)$. Specifically, where a personal crime is committed against a male victim by somebody known well, it is overwhelmingly by a non-intimate, whereas half of the 
comparable crimes against women are by intimates, primarily the hushaund.

Next, it seems important to examine the dynamics of report to the police of contact offences commitucd against men and women. Where the oflender was well known and the victim was male, four cases in ten came to the attention of the police. When the offender was well known and the victim was female, two cases in ten came to the attention of the police. Before accepting that this difference represents a greater reluctance of women to report offences against them by their intimates, it must be established whether the events themselves differed in the degree of harm inflicted according to victim gemder. If the crimes against women less often caused injury than crimes against men, this would provide the simplest explanation of the difference. The possibility that women victims may have been less injured is raised by looking at the reasons they gave for nom-report to the police of offences against them by people they knew well. 'They gave the reason 'too trivial' twice as often as male victims. The other reasons for non-report given more often by women are 'inappropriate', and 'dealt with ourselves'. Clearly, some classification of offences by degree of injury caused is essential. Fortunately, the British Crine Survey also provides information about whether the respondent was injured, and this allowed the compilation of the data in Table 3, on which log-lincar analysis was performed. The crucial interaction term in the analysis is the four-way term linking the variables in Table 3 . It is highly significant $\left(\mathrm{G}^{2}\right.$

TABIE 3

Relationships between Victim Gender, Injury Caused, Police Knowledge of Offence and Victim-Offender Relations: Incidents of Personal Crime from the British Crime Survey $1982(\mathrm{n}=$ weighted $\mathrm{n}$, total unweighted $\mathrm{n}=210)$

police came to police did not come

know of offence to know of offence

oflender offender offender offender

not known known not known known

or known well or known well

casually casually Total

\begin{tabular}{lccccc}
\hline $\begin{array}{l}\text { injured } \\
\text { male victim } \\
\text { uninjurcd }\end{array}$ & $43(34 \%)$ & $4(3 \%)$ & $67(53 \%)$ & $13(10 \%)$ & $127(100 \%)$ \\
$\begin{array}{l}\text { injured } \\
\text { female victim }\end{array}$ & $11(16 \%)$ & $12(18 \%)$ & $14(21 \%)$ & $30(45 \%)$ & $67(100 \%)$ \\
uninjured & $15(31 \%)$ & $0(0 \%)$ & $18(37 \%)$ & $16(33 \%)$ & $49(100 \%)$ \\
\hline Total & $97(29 \%)$ & $23(7 \%)$ & $150(45 \%)$ & $62(19 \%)$ & $332(100 \%)$
\end{tabular}


$=12.85,1 \mathrm{df}, \mathrm{p}<0.001)$. This means that there is a gender effect in the decision to report to the police which camot be accounted for solely in terms of the injury variable. The direction of the effect is that women are less likely to report to the police personal crimes against them. This difference is more marked when the offender is well known to the victim.

\section{Discussion}

This brief excursion into data from the British Crime Survey leads us to conclude that, despite the circumstances of the survey which must lead to an understatement of personal crime against women by those they know well, the problem of such crime is evident in the survey data. Further, it is a problem which does not often come to the attention of the police. The reasons given for non-report of the offences in question are primarily not those of anticipated police response. If this picture is supported by research of other kinds and in the 1984 British Crime Survey, it is arguable that the problem should be conceived as primarily one of the victim perceptions of the offences concened, rather than anticipated police responses to them: unless, that is, the anticipated responses of police oflicers and significant others socialises women into thinking of their victimisation in particular ways which lead to non-report.

Hanmer and Saunders (1984) canc to four major conclusions about women victims of attack. They were:

(i) The greater the uncertainty about the outcome, the more terrifying the encounter.

(ii) Specific violent offences are not sealed off into private versus public domains.

(iii) Women do not think the police in practice either able or willing to protect them.

(iv) Women are much more likely than the police to perceive violence to women as serious.

Some aspects of these conclusions are capable of test using data from the 1984 British Crime Survey. For instance, reasons for non-report which implicate anticipated police indifference will be available, as will be victim judgments of the scriousness of the offence suffered. Other aspects, like perceived outcome of attack, should be considered candidates for inclusion in future crime surveys.

\section{References}

Binney, V., Harkell, G. and Nixon, J. (1981) Leaving Violent Men, Iondon: Women's Aid Federation/Department of the Environment.

Braithwaite, J. (1984) Corporate Crime in the Pharmaceulical Industry, London: Routledge and Kegan Paul.

Dobash, R.E. and Dobash, R.P. (1980) Violence Against Wives, Icondon: Open Books.

Hanmer, J. and Saunders, S. (1984) W'ell-Founded Fear, Iondon: Hutchinson. 
Hough, J.M. and Mayhew, P.M. (1983) The Brilish Crime Survey: First Report (Home Oflice Research Study No. 76), London: H.M.S.O.

Hough, J.M. and Sheehy. K. (1986) Incidents of Violence: Findings from the British Crime Survey (Home Office Research Bulletin), in press.

Nelson, S. (1982) Incest: Fact and Myth, Edinburgh: Stramultion.

Owens, K.G. and Ashcroft, J.B. (1985) Violence: A Guide for the Caring Professions, london: Croom Helm.

Pattulo, P. (1983) Judging Women, London: N.C.C.L.

Stanley, L. and Wise, S. (1983) Breaking Out: Feminist Consciousness and Feminist Research, London: Routledge and Kegan Paul.

Wilson, E. (1983) What is to be Done about Violence Against Women?, Harmondsworth: Penguin. 